\title{
Synthesis and anti-juvenile hormone activity of ethyl 4-[(6-substituted 2,2-dimethyl-2H-chromen-7-yl)methoxy]benzoates
}

\author{
Kenjiro Furuta, ${ }^{\dagger, *}$ Norihiro FuJITA, Tsubasa IBUSHI, Takahiro ShIOTSUKI ${ }^{\dagger}$, \\ Naotaka YAMADA and Eiichi KUwANO \\ ${ }^{\dagger}$ National Institute of Agrobiological Sciences, Tsukuba, Ibaraki 305-8634, Japan \\ Laboratory of Pesticide Chemistry, Department of Applied Genetics and Pest Management, \\ Faculty of Agriculture, Kyushu University, Fukuoka 812-8581, Japan
}

(Received on December 26, 2009; Accepted April 17, 2010)

\begin{abstract}
Ethyl 4-[(6-substituted 2,2-dimethyl-2H-chromen-7-yl)methoxy]benzoates and their analogues were prepared and the biological activities were evaluated for both anti-juvenile hormone (anti-JH) and $\mathrm{JH}$ activity in silkworm larvae, Bombyx mori. Of the compounds tested, ethyl 4-[(6-methoxy-2,2-dimethyl-2H-chromen-7-yl)methoxy]benzoate (3b) showed the most effective precocious metamorphosis-inducing activity in 3rd instar larvae and JH activity in allatectomized 4th instar larvae. Furthermore, JH I and 20-hydroxyecdysone (20-E) titers in hemolymph of 3 rd instar larvae treated with $\mathbf{3 b}$ were measured by liquid chromatography-mass spectrometry (LCMS) and LC-MS/MS, respectively. The results revealed that compound $\mathbf{3 b}$ induced precocious metamorphosis by specifically decreasing JH I in hemolymph. (C) Pesticide Science Society of Japan
\end{abstract}

Key words: anti-juvenile hormone, juvenile hormone, 20-hydroxyecdysone, precocious metamorphosis.

\section{Introduction}

Juvenile hormones (JHs) are a class of regulatory sesquiterpenoids that play a crucial role in metamorphosis, diapause in immature insects and reproduction in adult insects. In the larval stage, molting and metamorphosis are regulated by JHs and ecdysteroid (molting hormone). ${ }^{1)} \mathrm{JHs}$ suppress adult differentiation and favor the maintenance of larval structures. A high titer of JHs must be present in the hemolymph for immature larvae to grow and pass through a series of larval molts induced by ecdysteroid secretion. Since JHs are involved in a wide range of physiological processes in insects, anti-JH agents, which interfere with the actions of JHs in insects, could be an effective tool for studies on insect physiology as well as a potential insect growth regulator (IGR). ${ }^{2)}$ Many anti$\mathrm{JH}$ agents, including precocenes, ethyl 4-[2-(tert-butylcarbonyloxy)butyloxy]benzoate (ETB) and brevioxime ${ }^{3)}$ have been reported. We have also found that ethyl 4-(2-benzylhexyloxy)benzoate (KF-13), by modifying the structure of ETB, strongly induced precocious metamorphosis against

\footnotetext{
* To whom correspondence should be addressed.

E-mail:ke.furuta@gmail.com

Published online June 18, 2010

(C) Pesticide Science Society of Japan
}

silkworm larvae, Bombyx mori. ${ }^{4}$ )

This study is an attempt to design and synthesize a new scaffold of anti-JH agents. We focused on the similarities in structures between $\mathrm{JHs}$ and retinoic acid. Interestingly, Palli and et al. have reported that two retinoic acid agonists showed weak $\mathrm{JH}$ activity in the black Manduca larval bioassay. ${ }^{5)}$ A number of compounds having a 1,2,3,4-tetrahydro-1,1,4,4tetramethynaphthalene ring are known as retinoid agonists or antagonists. ${ }^{6}$ Therefore, chromene derivatives having an oxygen atom in a 6-membered ring were designed on the basis of comparison of the structure of retinoids and JHs (Fig. 1), and their precocious metamorphosis-inducing activity against silkworm larvae was evaluated. In this paper, we described the preparation and structure-activity relationship of ethyl 4-

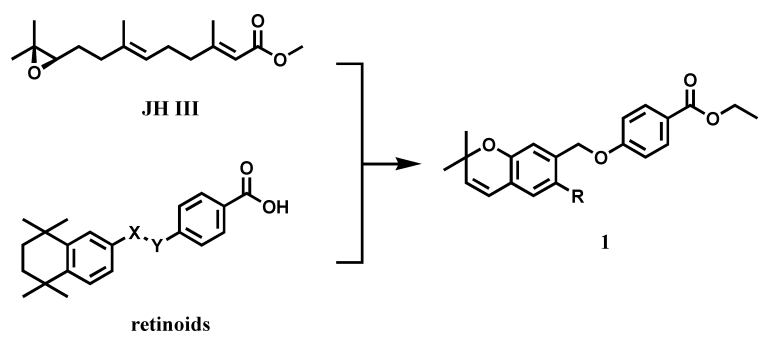

Fig. 1. Design of the chromene derivatives $\mathbf{1}$ on the basis of retinoids and JH III. 
[(6-substituted 2,2-dimethyl-2H-chromen-7-yl)methoxy]benzoates (1) and related derivatives, and furthermore, the effect of a representative compound, ethyl 4-[(6-methoxy-2,2-dimethyl-2H-chromen-7-yl)methoxy]benzoate (3b), on JH I, the major JH in silkworm larvae, and 20-hydroxyecdysone (20-E) titers in hemolymph.

\section{Materials and Methods}

\section{Instrumental Analysis and Chemicals}

${ }^{1} \mathrm{H}$ NMR spectra were determined with a JEOL EX-400 (400 $\mathrm{MHz}$ ) spectrometer, using tetramethylsilane as an internal standard, and all samples were prepared in deuteriochloroform. Methoprene was kindly supplied by Earth Biochemical Co.

\section{2,2-Dimethyl-2H-chromene-7-carbaldehyde (2a)}

To a solution of 2-methyl-3-butyn-2-ol $(1.0 \mathrm{~g}, 12 \mathrm{mmol})$ in acetonitrile $(10 \mathrm{ml})$ was added DBU $(2.71 \mathrm{~g}, 18 \mathrm{mmol})$ and trifluoroacetic anhydride $(2.75 \mathrm{~g}, 18 \mathrm{mmol})$ at $-5^{\circ} \mathrm{C}$. After the mixture was stirred for $30 \mathrm{~min}$ at the same temperature, a prepared solution of 3-hydroxybenzaldehyde (1.45 g, $12 \mathrm{mmol})$, DBU $(2.71 \mathrm{~g}, 18 \mathrm{mmol})$ and $\mathrm{CuCl}_{2}(10 \mathrm{mg})$ dissolved in acetonitrile $(10 \mathrm{ml})$ at $-5^{\circ} \mathrm{C}$ was added. Stirring was continued for $3 \mathrm{~h}$ at the same temperature, the product was extracted with ethyl acetate, and the extract was washed with $2 \mathrm{~N}$ aq. $\mathrm{HCl}, 2 \mathrm{~N}$ aq. $\mathrm{NaOH}$ and brine, dried over $\mathrm{Na}_{2} \mathrm{SO}_{4}$ and concentrated. The residue was purified by column chromatography on silica gel by eluting with $n$-hexane-ethyl acetate $(20: 1)$ to give $1.26 \mathrm{~g}$ crude propynyl ether as a dark brown oil. A solution of the above ether $(1.26 \mathrm{~g})$ in $N, N$-diethylaniline $(10 \mathrm{ml})$ was stirred for $2 \mathrm{~h}$ at $180^{\circ} \mathrm{C}$. The product was extracted with ethyl acetate and the extract was washed with $2 \mathrm{~N}$ aq. $\mathrm{HCl}$ and brine, dried over $\mathrm{Na}_{2} \mathrm{SO}_{4}$ and concentrated. The residue was purified by column chromatography on silica gel by eluting with $n$-hexane-ethyl acetate $(20: 1)$ to give $0.12 \mathrm{~g}(6 \%$; in two steps) of $2 \mathrm{a}$ as a yellow oil. ${ }^{1} \mathrm{H} \mathrm{NMR}\left(\mathrm{CDCl}_{3}\right) \delta: 1.46(6 \mathrm{H}, \mathrm{s}$, $\left.\mathrm{CH}_{3}\right), 5.79(1 \mathrm{H}, \mathrm{d}, J=9.8 \mathrm{~Hz}, \mathrm{CH}), 6.37(1 \mathrm{H}, \mathrm{d}, J=9.8 \mathrm{~Hz}$, $\mathrm{CH}), 7.10(1 \mathrm{H}, \mathrm{d}, J=7.8 \mathrm{~Hz}$, phenyl), $7.26(1 \mathrm{H}, \mathrm{s}$, phenyl), 7.35 (1H, d, $J=7.8 \mathrm{~Hz}$, phenyl), 9.88 (1H, s, CHO).

6-Methoxy-2,2-dimethyl-2H-chromene-7-carbaldehyde (2b)

A solution of phosphoryl chloride $(6.04 \mathrm{~g}, 39 \mathrm{mmol})$ in DMF $(2.88 \mathrm{~g}, 39 \mathrm{mmol})$ was stirred for $30 \mathrm{~min}$ at $0^{\circ} \mathrm{C}$. To the mixture was added a solution of 6-methoxy-2,2-dimethyl- $2 H$ chromene $(0.75 \mathrm{~g}, 3.9 \mathrm{mmol})$ in DMF $(2 \mathrm{ml})$. After stirring for $8 \mathrm{~h}$ at $80^{\circ} \mathrm{C}$, the reaction was quenched with $2 \mathrm{~N}$ aq. $\mathrm{NaOH}$ at $0^{\circ} \mathrm{C}$. The product was extracted with ethyl acetate and the extract was washed with $2 \mathrm{~N}$ aq. $\mathrm{HCl}$ and brine, dried over $\mathrm{Na}_{2} \mathrm{SO}_{4}$ and concentrated. The residue was purified by column chromatography on silica gel by eluting with $n$-hexaneethyl acetate $(8: 1)$ to give $0.32 \mathrm{~g}$ of $\mathbf{2} \mathbf{b}$, which was an approximately $5: 1$ mixture of 7-CHO and 5-CHO isomers.

Compounds $\mathbf{2 c - e}$ were prepared in the same manner as described above starting from the corresponding 6-alkyloxychromenes.

Ethyl 4-[(2,2-dimethyl-2H-chromen-7-yl)methoxy]ben- zoate (3a)

To a solution of $2 \mathrm{a}(0.12 \mathrm{~g}, 0.64 \mathrm{mmol})$ in methanol $(10 \mathrm{ml})$ was added $\mathrm{NaBH}_{4}(0.02 \mathrm{~g}, 0.64 \mathrm{mmol})$ at room temperature. After stirring for $1 \mathrm{~h}$, the product was extracted with ethyl acetate and the extract was washed with water and brine, dried over $\mathrm{Na}_{2} \mathrm{SO}_{4}$ and concentrated to give $0.12 \mathrm{~g}$ of crude 2,2-dimethyl-2H-chromene-7-methanol.

To a solution of the above alcohol $(0.12 \mathrm{~g})$ in THF $(5 \mathrm{ml})$ was added $\mathrm{Ph}_{3} \mathrm{P}(0.25 \mathrm{~g}, 0.95 \mathrm{mmol}), 40 \%$ diisopropyl azodicarboxylate $(0.48 \mathrm{~g}, 0.95 \mathrm{mmol})$ dissolved in toluene and ethyl $p$-hydroxybenzoate $(0.13 \mathrm{~g}, 0.95 \mathrm{mmol})$ at $0^{\circ} \mathrm{C}$. After stirring for $16 \mathrm{~h}$ at room temperature, the product was extracted with ethyl acetate. The extract was washed with $2 \mathrm{~N}$ aq. $\mathrm{NaOH}$ and brine, dried over $\mathrm{Na}_{2} \mathrm{SO}_{4}$ and concentrated. The residue was purified by column chromatography on silica gel by eluting with $n$-hexane-ethyl acetate $(20: 1)$ to give $0.02 \mathrm{~g}(9 \%)$ of $\mathbf{3 a}$ as a colorless oil. ${ }^{1} \mathrm{H}$ NMR $\left(\mathrm{CDCl}_{3}\right) \delta: 1.37(3 \mathrm{H}, \mathrm{t}, J=7.3 \mathrm{~Hz}$, $\left.\mathrm{CH}_{3}\right), 1.44\left(6 \mathrm{H}, \mathrm{s}, \mathrm{CH}_{3}\right), 4.33\left(2 \mathrm{H}, \mathrm{q}, J=7.3 \mathrm{~Hz}, \mathrm{OCH}_{2}\right), 5.03$ $\left(2 \mathrm{H}, \mathrm{s}, \mathrm{OCH}_{2}\right), 5.61(1 \mathrm{H}, \mathrm{d}, J=9.8 \mathrm{~Hz}, \mathrm{CH}), 6.33(1 \mathrm{H}, \mathrm{d}$, $J=9.8 \mathrm{~Hz}, \mathrm{CH}), 6.87(1 \mathrm{H}, \mathrm{s}$, phenyl), $6.89(1 \mathrm{H}, \mathrm{d}, J=7.8 \mathrm{~Hz}$, phenyl), 6.95 (2H, d, $J=8.8 \mathrm{~Hz}$, phenyl), $6.96(1 \mathrm{H}, \mathrm{d}, J=7.8$ $\mathrm{Hz}$, phenyl), 7.99 (2H, d, $J=8.8 \mathrm{~Hz}$, phenyl). Anal. Found: C, 74.54; $\mathrm{H}, 6.55 \%$. Calcd. for $\mathrm{C}_{21} \mathrm{H}_{22} \mathrm{O}_{4}$ : C, 74.15; $\mathrm{H}, 6.54 \%$.

Compounds $\mathbf{3 b}-\mathbf{e}$ were prepared in the same manner as described above starting from the corresponding 6-alkyloxy-7formylchromenes.

Ethyl 4-[(6-methoxy-2,2-dimethyl-2H-chromen-7-yl)methoxy]benzoate (3b)

Yield: $14 \%$ in two steps; ${ }^{1} \mathrm{H}$ NMR $\left(\mathrm{CDCl}_{3}\right) \delta: 1.38(3 \mathrm{H}, \mathrm{t}$, $\left.J=7.3 \mathrm{~Hz}, \mathrm{CH}_{3}\right), 1.40\left(6 \mathrm{H}, \mathrm{s}, \mathrm{CH}_{3}\right), 3.81\left(3 \mathrm{H}, \mathrm{s}, \mathrm{OCH}_{3}\right), 4.33$ $\left(2 \mathrm{H}, \mathrm{q}, J=7.3 \mathrm{~Hz}, \mathrm{OCH}_{2}\right), 5.09\left(2 \mathrm{H}, \mathrm{s}, \mathrm{OCH}_{2}\right), 5.63(1 \mathrm{H}, \mathrm{d}$, $J=7.8 \mathrm{~Hz}, \mathrm{CH}), 6.30(1 \mathrm{H}, \mathrm{d}, J=7.8 \mathrm{~Hz}, \mathrm{CH}), 6.54(1 \mathrm{H}, \mathrm{s}$, phenyl), 6.98 (1H, s, phenyl), $7.02(2 \mathrm{H}, \mathrm{d}, J=8.8 \mathrm{~Hz}$, phenyl), $7.98(2 \mathrm{H}, \mathrm{d}, J=8.8 \mathrm{~Hz}$, phenyl). Anal. Found: C, 71.13; H, $6.45 \%$. Calcd. for $\mathrm{C}_{22} \mathrm{H}_{24} \mathrm{O}_{5}: \mathrm{C}, 71.72 ; \mathrm{H}, 6.57 \%$.

Ethyl 4-[(6-ethoxy-2,2-dimethyl-2H-chromen-7-yl)methoxy]benzoate (3c)

Yield: $12 \%$ in two steps; ${ }^{1} \mathrm{H}$ NMR $\left(\mathrm{CDCl}_{3}\right) \delta: 1.37(3 \mathrm{H}, \mathrm{t}$, $\left.J=7.3 \mathrm{~Hz}, \mathrm{CH}_{3}\right), 1.39\left(3 \mathrm{H}, \mathrm{t}, J=7.3 \mathrm{~Hz}, \mathrm{CH}_{3}\right), 1.40(6 \mathrm{H}, \mathrm{s}$, $\left.\mathrm{CH}_{3}\right), 4.02\left(2 \mathrm{H}, \mathrm{q}, J=7.3 \mathrm{~Hz}, \mathrm{OCH}_{2}\right), 4.32(2 \mathrm{H}, \mathrm{q}, J=7.3 \mathrm{~Hz}$, $\left.\mathrm{OCH}_{2}\right), 5.10\left(2 \mathrm{H}, \mathrm{s}, \mathrm{OCH}_{2}\right), 5.61(1 \mathrm{H}, \mathrm{d}, J=7.8 \mathrm{~Hz}, \mathrm{CH}), 6.28$ $(1 \mathrm{H}, \mathrm{d}, J=7.8 \mathrm{~Hz}, \mathrm{CH}), 6.64(1 \mathrm{H}, \mathrm{s}$, phenyl), $6.89(1 \mathrm{H}, \mathrm{s}$, phenyl), 6.99 (2H, d, $J=8.8 \mathrm{~Hz}$, phenyl), 7.98 (2H, d, $J=8.8$ $\mathrm{Hz}$, phenyl). Anal. Found: C, 72.20; H, 6.88\%. Calcd. for $\mathrm{C}_{23} \mathrm{H}_{26} \mathrm{O}_{5}: \mathrm{C}, 72.23 ; \mathrm{H}, 6.85 \%$.

Ethyl 4-\{[2,2-dimethyl-6-(1-propoxy)-2H-chromen-7-yl]methoxy benzoate (3d)

Yield: $32 \%$ in two steps; ${ }^{1} \mathrm{H}$ NMR $\left(\mathrm{CDCl}_{3}\right) \delta: 1.02(3 \mathrm{H}, \mathrm{t}$, $\left.J=7.3 \mathrm{~Hz}, \mathrm{CH}_{3}\right), 1.38\left(3 \mathrm{H}, \mathrm{t}, J=7.3 \mathrm{~Hz}, \mathrm{CH}_{3}\right), 1.40(6 \mathrm{H}, \mathrm{s}$, $\left.\mathrm{CH}_{3}\right), 1.78\left(2 \mathrm{H}\right.$, sex, $\left.J=7.3 \mathrm{~Hz}, \mathrm{CH}_{2}\right), 3.92(2 \mathrm{H}, \mathrm{t}, J=7.3 \mathrm{~Hz}$, $\left.\mathrm{OCH}_{2}\right), 4.34\left(2 \mathrm{H}, \mathrm{q}, J=7.3 \mathrm{~Hz}, \mathrm{OCH}_{2}\right), 5.11\left(2 \mathrm{H}, \mathrm{s}, \mathrm{OCH}_{2}\right)$, $5.62(1 \mathrm{H}, \mathrm{d}, J=9.8 \mathrm{~Hz}, \mathrm{CH}), 6.28(1 \mathrm{H}, \mathrm{d}, J=9.8 \mathrm{~Hz}, \mathrm{CH}), 6.54$ (1H, s, phenyl), 6.90 (1H, s, phenyl), $6.98(2 \mathrm{H}, \mathrm{d}, J=8.8 \mathrm{~Hz}$, phenyl), 7.97 (2H, d, $J=8.8 \mathrm{~Hz}$, phenyl). Anal. Found: C, 
71.97; H, 7.09\%. Calcd. for $\mathrm{C}_{24} \mathrm{H}_{28} \mathrm{O}_{5}$ : C, 72.70; H, 7.12\%.

Ethyl 4-[(6-benzyloxy-2,2-dimethyl-2H-chromen-7-yl)methoxy]benzoate (3e)

Yield: $12 \%$ in two steps; ${ }^{1} \mathrm{H}$ NMR $\left(\mathrm{CDCl}_{3}\right) \delta: 1.36(3 \mathrm{H}, \mathrm{t}$, $\left.J=7.3 \mathrm{~Hz}, \mathrm{CH}_{3}\right), 1.41\left(6 \mathrm{H}, \mathrm{s}, \mathrm{CH}_{3}\right), 4.33(2 \mathrm{H}, \mathrm{q}, J=7.3 \mathrm{~Hz}$, $\left.\mathrm{OCH}_{2}\right), 5.06\left(2 \mathrm{H}, \mathrm{s}, \mathrm{OCH}_{2}\right), 5.13\left(2 \mathrm{H}, \mathrm{s}, \mathrm{OCH}_{2}\right), 5.62(1 \mathrm{H}, \mathrm{d}$, $J=9.8 \mathrm{~Hz}, \mathrm{CH}), 6.27(1 \mathrm{H}, \mathrm{d}, J=9.8 \mathrm{~Hz}, \mathrm{CH}), 6.62(1 \mathrm{H}, \mathrm{s}$, phenyl), $6.91(1 \mathrm{H}, \mathrm{s}$, phenyl), $6.97(2 \mathrm{H}, \mathrm{d}, J=8.8 \mathrm{~Hz}$, phenyl), 7.31-7.40 (5H, m, phenyl), $7.96(2 \mathrm{H}, \mathrm{d}, J=8.8 \mathrm{~Hz}$, phenyl). Anal. Found: C, 75.29; H, 6.35\%. Calcd. for $\mathrm{C}_{28} \mathrm{H}_{28} \mathrm{O}_{5}: \mathrm{C}$, $75.65 ; \mathrm{H}, 6.35 \%$.

Ethyl 4-[(6-methoxy-2,2-dimethylchroman-7-yl)methoxy]benzoate (4)

A solution of 6-methoxy-2,2-dimethyl-2H-chromene-7methanol $(0.15 \mathrm{~g}, 0.68 \mathrm{mmol})$ in methanol $(5 \mathrm{ml})$ containing $\mathrm{Pd} / \mathrm{C}(0.01 \mathrm{~g})$ was stirred for $16 \mathrm{~h}$ at room temperature under a hydrogen atmosphere. After filtration, the product was extracted with ethyl acetate. The extract was washed with water and brine, dried over $\mathrm{Na}_{2} \mathrm{SO}_{4}$ and concentrated. The residue was purified by column chromatography on silica gel by eluting with $n$-hexane-ethyl acetate $(3: 1)$ to give $0.15 \mathrm{~g}$ of crude 6-methoxy-2,2-dimethylchroman-7-methanol.

To a solution of the above alcohol $(0.15 \mathrm{~g})$ in THF $(5 \mathrm{ml})$ at $0^{\circ} \mathrm{C}$ was added $\mathrm{Ph}_{3} \mathrm{P}(0.37 \mathrm{~g}, 1.4 \mathrm{mmol}), 40 \%$ diisopropyl diazocarboxylate in toluene $(0.71 \mathrm{~g}, 1.4 \mathrm{mmol})$ and ethyl $p$-hydroxybenzoate $(0.20 \mathrm{~g}, 1.2 \mathrm{mmol})$. After stirring for $16 \mathrm{~h}$ at room temperature, the product was extracted with ethyl acetate and the extract was washed with $2 \mathrm{~N}$ aq. $\mathrm{NaOH}$ and brine, dried over $\mathrm{Na}_{2} \mathrm{SO}_{4}$ and concentrated. The residue was purified by column chromatography on silica gel by eluting with $n$-hexane-ethyl acetate $(10: 1)$ to give $0.14 \mathrm{~g}$ ( $43 \%$ in two steps) of 4 as a colorless oil. ${ }^{1} \mathrm{H}-\mathrm{NMR}\left(\mathrm{CDCl}_{3}\right) \delta: 1.31$ $\left(6 \mathrm{H}, \mathrm{s}, \mathrm{CH}_{3}\right), 1.37\left(3 \mathrm{H}, \mathrm{t}, J=7.3 \mathrm{~Hz}, \mathrm{CH}_{3}\right), 1.78(2 \mathrm{H}, \mathrm{t}$, $\left.J=6.8 \mathrm{~Hz}, \mathrm{CH}_{2}\right), 2.77\left(2 \mathrm{H}, \mathrm{t}, J=6.8 \mathrm{~Hz}, \mathrm{CH}_{2}\right), 3.80(3 \mathrm{H}, \mathrm{s}$, $\left.\mathrm{OCH}_{3}\right), 4.34\left(2 \mathrm{H}, \mathrm{q}, J=6.8 \mathrm{~Hz}, \mathrm{OCH}_{2}\right), 5.08\left(2 \mathrm{H}, \mathrm{s}, \mathrm{OCH}_{2}\right)$, $6.60(1 \mathrm{H}, \mathrm{s}$, phenyl), $6.69(1 \mathrm{H}, \mathrm{s}$, phenyl $), 6.99(2 \mathrm{H}, \mathrm{d}$, $J=8.8 \mathrm{~Hz}$, phenyl), $7.98(2 \mathrm{H}, \mathrm{d}, J=8.8 \mathrm{~Hz}$, phenyl). Anal. Found: $\mathrm{C}, 70.98 ; \mathrm{H}, 7.14 \%$. Calcd. for $\mathrm{C}_{22} \mathrm{H}_{26} \mathrm{O}_{5}: \mathrm{C}, 71.33 ; \mathrm{H}$, $7.07 \%$.

7-Methoxy-1,4-benzodioxan-6-carbaldehyde (6a)

To a solution of 6-hydroxy-1,4-benzodioxane $(5 \mathrm{a}, 1.05 \mathrm{~g}$, $7 \mathrm{mmol})$ in THF $(10 \mathrm{ml})$ at $0^{\circ} \mathrm{C}$ was added $2.0 \mathrm{M}$ ethyl magnesium chloride in THF $(17.3 \mathrm{ml}, 36 \mathrm{mmol})$, and the mixture was stirred for $30 \mathrm{~min}$ at room temperature. After removing the solvent under reduced pressure, the residue was dissolved in benzene $(10 \mathrm{ml})$ and hexamethylphosphoric triamide $(3.09 \mathrm{~g}, 17 \mathrm{mmol})$, and cooled at $0^{\circ} \mathrm{C}$. Paraformaldehyde $(3.0 \mathrm{~g})$ was added to the mixture. After stirring for $4 \mathrm{~h}$ at $80^{\circ} \mathrm{C}$, the product was extracted with ethyl acetate and the extract was washed with $2 \mathrm{~N}$ aq. $\mathrm{HCl}$ and brine, dried over $\mathrm{Na}_{2} \mathrm{SO}_{4}$ and concentrated. The residue was purified by column chromatography on silica gel by eluting with $n$-hexaneethyl acetate $(3: 1)$ to give $0.64 \mathrm{~g}$ crude 7 -hydroxy-1,4-benzodioxan-6-carbaldehyde.
To a solution of the above aldehyde $(0.15 \mathrm{~g})$ in DMF $10 \mathrm{ml}$ was added $\mathrm{K}_{2} \mathrm{CO}_{3}(0.12 \mathrm{~g}, 0.9 \mathrm{mmol})$ and methyl iodide $(0.13 \mathrm{~g}, 0.9 \mathrm{mmol})$. After stirring for $4 \mathrm{~h}$ at $80^{\circ} \mathrm{C}$, the product was extracted with ethyl acetate and the extract was washed with $2 \mathrm{~N}$ aq. $\mathrm{NaOH}$ and brine, dried over $\mathrm{Na}_{2} \mathrm{SO}_{4}$ and concentrated. The residue was purified by column chromatography on silica gel by eluting with $n$-hexane-ethyl acetate $(7: 1)$ to give $1.05 \mathrm{~g}\left(78 \%\right.$ in two steps) of $\mathbf{6 a}$ as a pale yellow oil. ${ }^{1} \mathrm{H}$ NMR $\left(\mathrm{CDCl}_{3}\right) \delta: 3.84\left(3 \mathrm{H}, \mathrm{s}, \mathrm{OCH}_{3}\right), 4.21-4.24(2 \mathrm{H}, \mathrm{m}$, $\left.\mathrm{OCH}_{2}\right), 4.31-4.33\left(2 \mathrm{H}, \mathrm{m}, \mathrm{OCH}_{2}\right), 6.46(1 \mathrm{H}, \mathrm{s}$, phenyl $), 7.36$ (1H, s, phenyl), $10.27(1 \mathrm{H}, \mathrm{s}, \mathrm{CHO})$.

Compounds $\mathbf{6 b}$ and $\mathbf{6 c}$ were similarly prepared by a similar method starting from the corresponding phenol.

3-Methoxy-5, 6, 7,8-tetrahydronaphthalene-2-carbaldehyde (6b)

Yield: $7 \%$ in two steps; ${ }^{1} \mathrm{H}$ NMR $\left(\mathrm{CDCl}_{3}\right) \delta: 1.74-1.80$ $\left(4 \mathrm{H}, \mathrm{m}, \mathrm{CH}_{2}\right), 2.66-2.74\left(4 \mathrm{H}, \mathrm{m}, \mathrm{CH}_{2}\right), 3.88\left(3 \mathrm{H}, \mathrm{s}, \mathrm{OCH}_{3}\right)$, $6.66(1 \mathrm{H}, \mathrm{s}$, naphthyl), $7.26(1 \mathrm{H}, \mathrm{s}$, naphthyl), $10.40(1 \mathrm{H}, \mathrm{s}$, $\mathrm{CHO})$.

\section{2,4,5-trimethoxybenzaldehyde (6c)}

Yield: $80 \%$ in two steps; ${ }^{1} \mathrm{H}$ NMR $\left(\mathrm{CDCl}_{3}\right) \delta: 3.98(3 \mathrm{H}, \mathrm{s}$, $\left.\mathrm{OCH}_{3}\right), 3.93\left(3 \mathrm{H}, \mathrm{s}, \mathrm{OCH}_{3}\right), 3.98\left(3 \mathrm{H}, \mathrm{s}, \mathrm{OCH}_{3}\right), 6.50(1 \mathrm{H}, \mathrm{s}$, phenyl), 7.33 (1H, s, phenyl), $10.30(1 \mathrm{H}, \mathrm{s}, \mathrm{CHO})$.

Compounds $\mathbf{7 a - c}$ were prepared in the same manner as described above for the preparation of compound 3a.

Ethyl 4-[(7-methoxy-1,4-benzodioxan-6-yl)methoxy]benzoate (7a)

Yield: $27 \%$ in two steps; ${ }^{1} \mathrm{H}$ NMR $\left(\mathrm{CDCl}_{3}\right) \delta: 1.38(3 \mathrm{H}, \mathrm{t}$, $\left.J=7.3 \mathrm{~Hz}, \mathrm{CH}_{3}\right), 4.19-4.25\left(4 \mathrm{H}, \mathrm{m}, \mathrm{OCH}_{2}\right), 4.34(2 \mathrm{H}, \mathrm{q}$, $\left.J=7.3 \mathrm{~Hz}, \mathrm{OCH}_{2}\right), 5.03\left(2 \mathrm{H}, \mathrm{s}, \mathrm{OCH}_{2}\right), 5.10\left(2 \mathrm{H}, \mathrm{s}, \mathrm{OCH}_{2}\right)$, $6.52(1 \mathrm{H}, \mathrm{s}$, phenyl), $6.95(1 \mathrm{H}, \mathrm{s}$, phenyl), $6.97(2 \mathrm{H}, \mathrm{d}, J=8.8$ Hz, phenyl), 7.36-7.42 (5H, m, phenyl), 7.97 ( $2 \mathrm{H}, \mathrm{d}, J=8.8$ $\mathrm{Hz}$, phenyl). Anal. Found: C, 66.07; H, 5.92\%. Calcd. for $\mathrm{C}_{19} \mathrm{H}_{20} \mathrm{O}_{6}: \mathrm{C}, 66.27 ; \mathrm{H}, 5.85 \%$.

Ethyl 4-[(3-methoxy-5, 6, 7,8-tetrahydronaphth-2-yl)methoxy]benzoate (7b)

Yield: $36 \%$ in two steps; ${ }^{1} \mathrm{H}$ NMR $\left(\mathrm{CDCl}_{3}\right) \delta: 1.38(3 \mathrm{H}, \mathrm{t}$, $\left.J=7.3 \mathrm{~Hz}, \mathrm{CH}_{3}\right), 1.77-1.79\left(4 \mathrm{H}, \mathrm{m}, \mathrm{CH}_{2}\right), 2.68-2.76(2 \mathrm{H}, \mathrm{m}$, $\left.\mathrm{CH}_{2}\right), 2.77-2.79\left(2 \mathrm{H}, \mathrm{m}, \mathrm{CH}_{2}\right), 3.82\left(3 \mathrm{H}, \mathrm{s}, \mathrm{OCH}_{3}\right), 4.34(2 \mathrm{H}$, q, $\left.J=7.3 \mathrm{~Hz}, \mathrm{OCH}_{2}\right), 5.09\left(2 \mathrm{H}, \mathrm{s}, \mathrm{OCH}_{2}\right), 6.68(1 \mathrm{H}, \mathrm{s}$, naphthyl), $7.03(2 \mathrm{H}, \mathrm{d}, J=8.8 \mathrm{~Hz}$, phenyl), $7.05(1 \mathrm{H}, \mathrm{s}$, naphthyl), $8.01(2 \mathrm{H}, \mathrm{d}, J=8.8 \mathrm{~Hz}$, phenyl). Anal. Found: C, 73.88; H, $7.25 \%$. Calcd. for $\mathrm{C}_{21} \mathrm{H}_{24} \mathrm{O}_{4}: \mathrm{C}, 74.09 ; \mathrm{H}, 7.11 \%$.

Ethyl 4-(2,4,5-trimethoxybenzyloxy)benzoate (7c)

Yield: $12 \%$ in two steps; ${ }^{1} \mathrm{H}$ NMR $\left(\mathrm{CDCl}_{3}\right) \delta: 1.38(3 \mathrm{H}, \mathrm{t}$, $\left.J=7.3 \mathrm{~Hz}, \mathrm{CH}_{3}\right), 3.84\left(3 \mathrm{H}, \mathrm{s}, \mathrm{OCH}_{3}\right), 3.86\left(3 \mathrm{H}, \mathrm{s}, \mathrm{OCH}_{3}\right)$, $3.91\left(3 \mathrm{H}, \mathrm{s}, \mathrm{OCH}_{3}\right), 4.34\left(2 \mathrm{H}, \mathrm{q}, J=7.3 \mathrm{~Hz}, \mathrm{OCH}_{2}\right), 5.10(2 \mathrm{H}$, s, $\left.\mathrm{OCH}_{2}\right), 6.56(1 \mathrm{H}, \mathrm{s}$, phenyl), $6.97(1 \mathrm{H}, \mathrm{s}$, phenyl), $7.00(2 \mathrm{H}$, d, $J=8.8 \mathrm{~Hz}$, phenyl), 7.99 ( $2 \mathrm{H}, \mathrm{d}, J=8.8 \mathrm{~Hz}$, phenyl). Anal. Found: $\mathrm{C}, 65.39 ; \mathrm{H}, 6.45 \%$. Calcd. for $\mathrm{C}_{19} \mathrm{H}_{22} \mathrm{O}_{6}: \mathrm{C}, 65.88 ; \mathrm{H}$, $6.40 \%$.

\section{Biological Evaluation}

B. mori (Shunrei $\times$ Shougetsu) larvae were reared on an artifi- 
cial diet. ${ }^{7)}$ The anti-JH activity of compounds was evaluated by the induction of precocious metamorphosis when topically applied to the dorsal abdomen of 24-hr-old 3rd instar larvae. The JH activity of compounds was evaluated by molting into normal 5th instars when topically applied to allatectomized 24-hr-old 4th instar larvae. ${ }^{8)}$

\section{Quantification of JH and 20-E in hemolymph}

\subsection{Reagents and glassware}

JH I and II were purchased from SciTech (Prague, Czech Republic) and JH III was from Sigma-Aldrich (St. Louis, MO), respectively, and purified by LC-MS with a silica gel column (SG-80, 10×250 mm; Shiseido, Tokyo, Japan) using 10\% diethyl ether in $n$-hexane as the normal phase. Deuterium-labeled JH III ( $\mathrm{JH} \mathrm{III-}_{3}$ ) as the internal standard was prepared according to the previous report.9) 20 -Hydroxyecdysone and ponasterone A were purchased from Sigma-Aldrich.

All solvents used were of residual pesticide analysis grade (5000-fold concentrate guaranteed; Wako Pure Chemicals, Osaka, Japan). All glassware was rinsed sequentially with distilled water, acetone and $n$-hexane, and heated overnight at $500^{\circ} \mathrm{C}$ before use.

3.2. Collection of hemolymph samples

Ten micrograms of compound $\mathbf{3} \mathbf{b}$ in acetone solution $(1 \mu \mathrm{l})$ was applied topically to 24 -hr-old 3rd instar of B. mori larvae. An abdominal leg was cut and hemolymph was collected in microtubes containing approx. $5 \%(\mathrm{w} / \mathrm{v})$ phenylthiourea and $1 \mathrm{mM}$ EDTA every $24 \mathrm{hr}$. Samples were stored at $-80^{\circ} \mathrm{C}$ until used.

\subsection{Purification of JH I from hemolymph and analytical conditions for LC-MS}

Clean-up was carried out by slightly modifying the method described for JH quantification using GC-MS. ${ }^{10)}$ Briefly, $10 \mu 1$ JH III- $\mathrm{d}_{3}$ in toluene $(67.1 \mathrm{pg} / \mu \mathrm{l})$ as an internal standard was transferred into a clean glass tube, and $0.5 \mathrm{ml}$ methanol was added. To this solution was added the hemolymph (100 $\mu 1)$, the mixture was vortexed vigorously, and $1.5 \mathrm{ml}$ of $2 \% \mathrm{NaCl}$ solution was added to the sample solution. JHs were extracted by the partition of $n$-hexane $(0.5 \mathrm{ml})$ three times. The combined extracts $(1.5 \mathrm{ml})$ were purified using a Pasture pipette packed with $1.0 \mathrm{~g}$ aluminum oxide (activity grade III; ICN Ecochrom, Germany) prewashed with $n$-hexane. After loading the extract, JH I was eluted with $2 \mathrm{ml}$ of $50 \%$ ether in $n$ hexane and then the solvent was removed under a stream of nitrogen. The residue was dissolved in acetonitrile $(25 \mu \mathrm{l})$.

The Applied Biosystems API2000 LC-MS system was used. The analytical condition was optimized referring to the method reported previously. ${ }^{11)}$ The samples were separated on a $3 \times 150 \mathrm{~mm} \mathrm{C}_{18}$ reversed phase column (UG80; Shiseido) with $70 \%$ acetonitrile containing the appropriate sodium salt at a flow rate of $0.4 \mathrm{ml} / \mathrm{min}$. For MS analysis, electrospray ionization (ESI) in the positive mode was used under the conditions of drying gas temperature $400^{\circ} \mathrm{C}$ with $101 / \mathrm{min}$ flow rate and $15 \mathrm{~V}$ declustering potential (DP). Selected ion masses
(SIM) for each $\mathrm{JH}$ were monitored as $[\mathrm{M}+\mathrm{Na}]^{+}$, that is, $m / z$ 292 and 317 for JH III-d $\mathrm{d}_{3}$ and JH I, respectively.

3.4. Purification of 20-E from hemolymph and analytical condition for $L C-M S / M S$

Ponasterone A $(5 \mathrm{ng} / \mu \mathrm{l})$ in $10 \mu \mathrm{l}$ methanol as an internal standard was transferred into a microtube, and $300 \mu 1$ methanol was added. To this solution was added the hemolymph $(20 \mu 1)$, and the mixture was vortexed vigorously and centrifuged at $13000 \mathrm{rpm}$ for $10 \mathrm{~min}$. The supernatant was collected in new microtubes, and the pellet was re-extracted with $300 \mu 1$ methanol. The combined methanol extracts $(600 \mu 1)$ were evaporated to dryness under a vacuum. The residue was dissolved in $100 \mu \mathrm{l}$ of $80 \%$ methanol in water.

The Applied Biosystems API2000 LC-MS/MS system equipped with a $3 \times 150 \mathrm{~mm} \mathrm{C}_{18}$ reversed phase column (MG80; Shiseido) was used. The solvents were deionized water containing $0.01 \%$ formic acid (solvent $\mathrm{A}$ ) and acetonitrile. ${ }^{12)}$ A linear solvent gradient was used starting from 5\% acetonitrile in solvent A to $100 \%$ acetonitrile over $15 \mathrm{~min}$, followed by elution with $100 \%$ acetonitrile for $5 \mathrm{~min}$ at a flow rate of $0.3 \mathrm{ml} / \mathrm{min}$. For MS/MS analysis, ESI in the positive mode with nitrogen as collision gas was used under the conditions of drying gas temperature $500^{\circ} \mathrm{C}$ with $10 \mathrm{l} / \mathrm{min}$ flow rate. Then, 20-E and ponasterone A were detected with multiple reaction monitoring (MRM) transition; $m / z 481[\mathrm{M}+\mathrm{H}]^{+} \rightarrow$ $445\left[\mathrm{M}+\mathrm{H}-2 \mathrm{H}_{2} \mathrm{O}\right]^{+}$(DP: $66 \mathrm{~V}$, collision energy (CE): $23 \mathrm{~V}$ ) and $m / z 465[\mathrm{M}+\mathrm{H}]^{+} \rightarrow 429\left[\mathrm{M}+\mathrm{H}-2 \mathrm{H}_{2} \mathrm{O}\right]^{+}(\mathrm{DP}: 61 \mathrm{~V}, \mathrm{CE}$ : $23 \mathrm{~V})$, respectively.

\section{Results and Discussion}

\section{Synthesis}

The synthesis of a series of ethyl 4-[(6-substituted 2,2-dimethyl-2H-chromen-7-yl)methoxy]benzoates and related derivatives is outlined in Fig. 2(A) and (B). Chromene 2a was prepared via alkylation of 3-hydroxybenzaldehyde with 2methyl-3-butyn-2-ol and trifluoroacetic anhydride in the presence of $\mathrm{DBU}$ and $\mathrm{CuCl}_{2}$, and cyclization under heating in $\mathrm{N}, \mathrm{N}$-dimethylaniline at $180^{\circ} \mathrm{C} .{ }^{13)}$ 6-Substituted chromene (I) was formylated by the Vilsmeier procedure, and aldehydes 2b-e were yielded as approximately 5:1 mixtures of 7$\mathrm{CHO}$ and 5-CHO isomers. In the case of phenols $\mathbf{5 a - c}$, formylation $^{14)}$ was carried out via the magnesium chloride salt of the phenol to yield the o-hydroxyaldehyde exclusively, which was treated with methyl iodide to afford aldehydes $\mathbf{6 a}-\mathbf{c}$. Reduction of the aldehyde group in $\mathbf{2 a}-\mathbf{e}$ and $\mathbf{6 a}-\mathbf{c}$ with $\mathrm{NaBH}_{4}$, followed by the Mitsunobu reaction with ethyl $p$-hydroxybenzoate gave compounds $\mathbf{3 a}-\mathbf{e}$ and $\mathbf{7 a}-\mathbf{c}$, respectively.

\section{Anti-JH activity of chromenes and related compounds}

Table 1 shows the precocious metamorphosis-inducing activity of ethyl 4-[(6-substituted 2,2-dimethyl-2H-chromen-7-yl)methoxy]benzoates and related compounds against 3rd instar larvae of B. mori. Compound 3a showed weak precocious metamorphosis-inducing activity. Introduction of a methoxy 
(A)
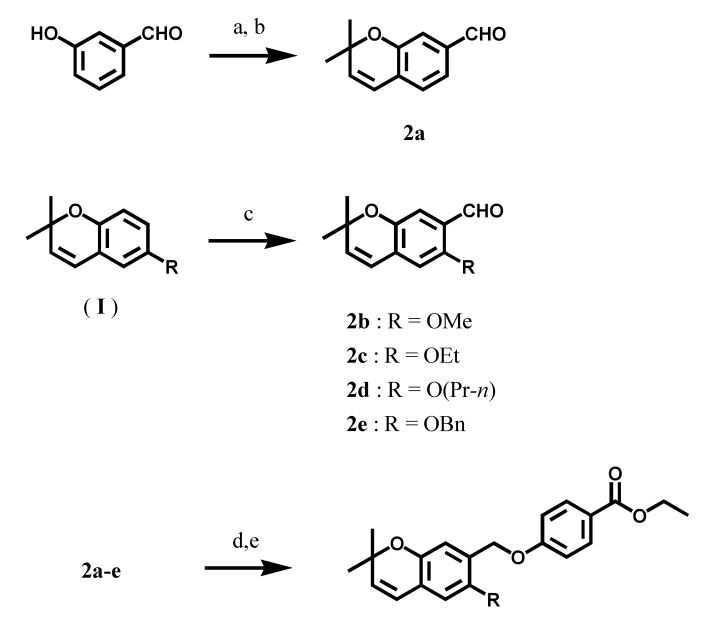

3a-e

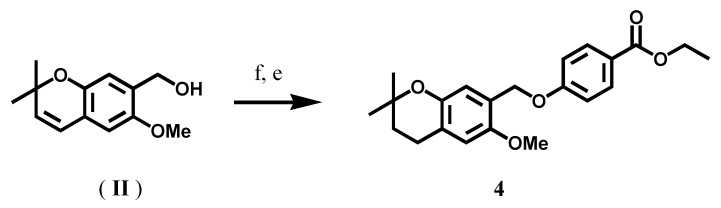

(B)

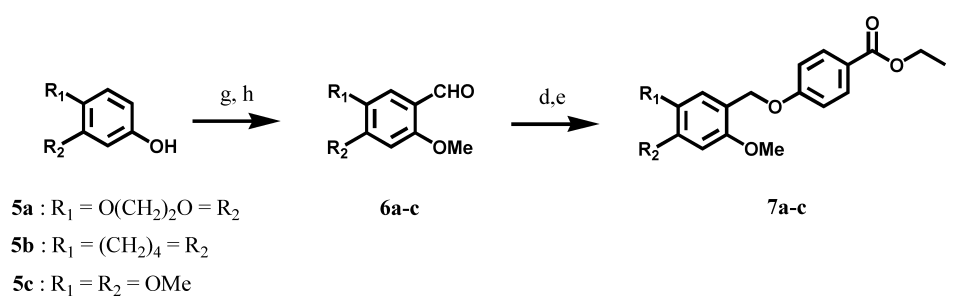

Fig. 2. Synthetic scheme for the preparation of (A) chromene derivatives and (B) benzodioxan, tetraline and dimethoxybenzene derivatives. (a) 2-methyl-3-butyn-2-ol, trifluoroacetic anhydride, $\mathrm{DBU}, \mathrm{CuCl}_{2}$, acetonitrile; (b) $\mathrm{N}, \mathrm{N}$-diethylaniline; (c) DMF, phosphoryl chloride; (d) $\mathrm{NaBH}_{4}$, methanol; (e) ethyl 4-hydroxybenzoate, $\left(\mathrm{C}_{6} \mathrm{H}_{5}\right)_{3}$ P, diisopropyl azodicarboxylate (DIAD), THF; (f) $\mathrm{H}_{2}$, Pd/C, methanol; (g) ethyl magnesium chloride, paraformaldehyde, HMPA, THF; (h) methyl iodide, $\mathrm{K}_{2} \mathrm{CO}_{3}$, DMF.

group at 6-position on the chromene ring (3b) led to the marked increase of anti-JH activity, showing $100 \%$ induction of precocious metamorphosis at $40 \mu \mathrm{g}$; however, when a longer alkyloxy substituent, such as an ethoxy (3c) and a $n$ propoxy (3d) group, was introduced, their anti-JH activity was markedly decreased. Interestingly, the benzyloxy analog $\mathbf{3 e}$ exhibited almost the same level of activity as $\mathbf{3 b}$, suggesting that the size of the substituent of C-6 on the chromene ring was significantly not a critical factor for anti-JH activity.

Precocene II possessing a 2,2-dimethyl-2H-chromene skeleton was the first compound to show anti-JH activity. ${ }^{15)}$ Concerning its mode of action, the double bond of the chromene ring is readily oxidized by $\mathrm{P} 450$ in the corpora allata to the epoxide intermediate, a powerful alkylating property, which reacts with cellular macromolecular constituents to destroy the cells of the corpora allata. Therefore, in precocene II, the double bond is indispensable for anti-JH activ- ity. To examine whether the double bond in the chromene ring of $\mathbf{3 b}$ was essential for anti-JH activity, the chroman derivative $\mathbf{4}$ was synthesized. Chroman $\mathbf{4}$ showed slightly lower anti$\mathrm{JH}$ activity than the corresponding chromene $\mathbf{3} \mathbf{b}$, suggesting that the mode of action of these derivatives is different from that of precocene II. Benzodioxan derivative 7a showed somewhat lower activity than those of $\mathbf{3 b}$ and $\mathbf{4}$. On the other hand, the anti-JH activity of tetraline derivative $7 \mathbf{b}$ was markedly decreased, and 4,5-dimethoxy derivative 7c did not show any activity. These results indicate that the ring structure containing an oxygen atom adjacent to the benzene ring is significant for anti-JH activity.

3. JH activity of chromene and chroman derivatives Table 2 shows the $\mathrm{JH}$ activity of methoprene, chromene $\mathbf{3 b}$ and chroman 4 against allatectmized 4th instar larvae. All allatectomized and acetone-treated control larvae underwent 
Table 1. Precocious metamorphosis-inducing activity of ethyl 4-[(6-substituted 2,2-dimethyl-2H-chromen-7-yl)methoxy]benzoates and related compounds against 3 rd instar larvae of $B$. mori.

\begin{tabular}{ccrcc}
\hline & & \multicolumn{3}{c}{ Precocious metamorphosis ${ }^{a}(\%)$} \\
\cline { 3 - 5 } Compound & $\mathrm{R}$ & 1 & 10 & $40(\mu \mathrm{g} /$ larva $)$ \\
\hline 3a & $\mathrm{H}$ & 0 & 20 & 65 \\
3b & OMe & 75 & 95 & 100 \\
3c & OEt & 0 & 5 & 20 \\
3d & O(Pr- $n)$ & 0 & 0 & 16 \\
3e & OBn & 40 & 100 & 100 \\
4 & & 46 & 94 & 87 \\
7a & & 10 & 58 & 79 \\
7b & & 0 & 10 & 30 \\
7c & & 0 & 0 & 0 \\
\hline
\end{tabular}

${ }^{a)}$ Values are the average of two experiments.

precocious metamorphosis. Compounds $\mathbf{3 b}$ and $\mathbf{4}$ as well as methoprene completely prevented precocious metamorphosis at a high dose of $40 \mu \mathrm{g}$ so that all treated larvae molted into 5 th larvae. The JH activity of compound $\mathbf{3 b}$ at $1 \mu \mathrm{g}$ was lower than that of methoprene. Thus, in analogy with the ethyl 4-(2benzylalkyloxy)benzoate series, ${ }^{4)}$ these compounds were found to show both anti-JH and JH activity.

\section{Changes in JH I and 20-E titers in hemolymph after topical application of compound $\mathbf{3} \boldsymbol{b}$}

The JH I titer in hemolymph of larvae treated with $10 \mu \mathrm{g}$ compound $\mathbf{3 b}$ was determined by LC-MS from the day when treated to 3 rd instar larvae through pupation (Fig. 3A). In controls, the JH I titer decreased just before ecdysis to 4th instar, and sharply increased to as high as $4.60 \pm 2.02 \mathrm{ng} / \mathrm{ml}$ after

Table 2. Effects of methoprene, $\mathbf{3 b}$ and $\mathbf{4}$ on the development of allatectomized 4 th instar larvae of $B$. mori.

\begin{tabular}{lcccc}
\hline \multirow{2}{*}{ Treatment } & & \multicolumn{3}{c}{ Number of larvae transformed into ${ }^{a)}$} \\
\cline { 3 - 5 } & $\begin{array}{c}\text { Dose } \\
(\mu \mathrm{g} / \text { larva })\end{array}$ & $\begin{array}{c}\text { Precocious } \\
\text { pupa }\end{array}$ & $\begin{array}{c}\text { Larval- } \\
\text { pupa } \\
\text { intermediate }\end{array}$ & $\begin{array}{c}\text { 5th instar } \\
\text { larva }\end{array}$ \\
\hline $\begin{array}{l}\text { Allatectomized } \\
\text { control }\end{array}$ & & 10 & 0 & 0 \\
+ methoprene & 1 & 0 & 0 & 10 \\
$+3 \mathbf{3 b}$ & 1 & 2 & 6 & 2 \\
& 40 & 0 & 0 & 10 \\
$+\mathbf{4}$ & 40 & 0 & 0 & 10 \\
\hline
\end{tabular}

${ }^{a)}$ Number of larvae tested: 10 .
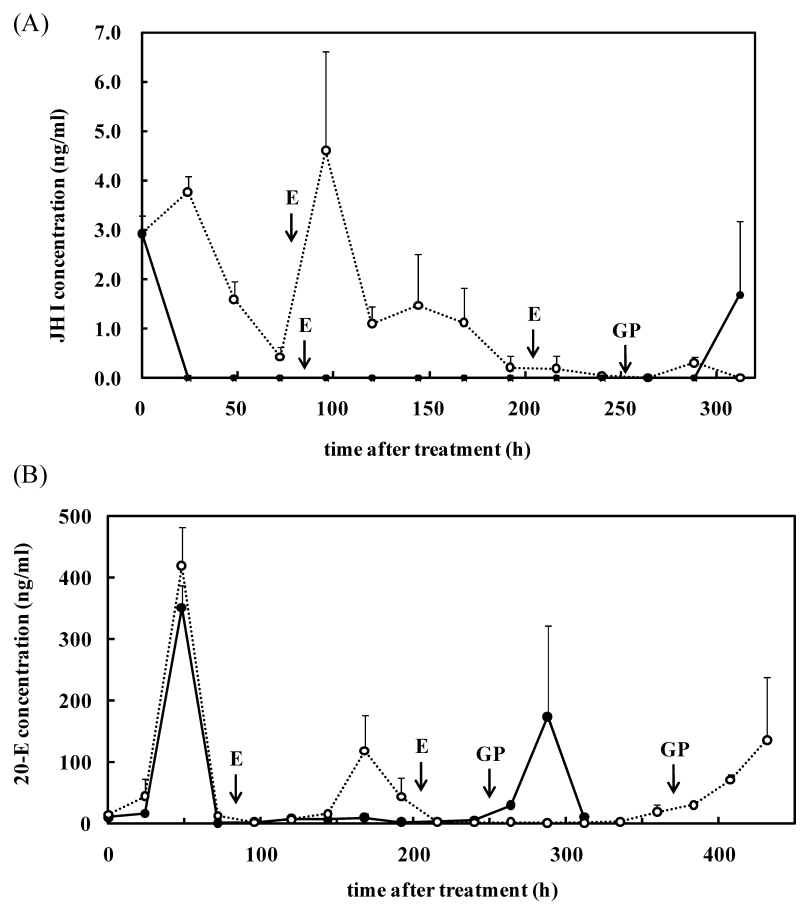

Fig. 3. Effect of treatment with compound $\mathbf{3 b}$ on changes in JH I (A) and 20-E (B) titers in hemolymph. Open circle, control larvae; closed circle, compound 3b-treated larvae. E, Ecdysis; GP, Gut Parge. Titers of JH I and 20-E were determined by LC-MS and LCMS/MS, respectively. The data are the means \pm S.D. $(n=4)$

ecdysis. In contrast to the results obtained by radioimmunoassay, ${ }^{16)}$ no JH I was observed in the early stage of 5 th larvae. Topical application of compound $\mathbf{3} \mathbf{b}$ caused a marked drop in the JH I titer within $24 \mathrm{hr}$ after treatment and JH I was not detected $(<0.1 \mathrm{ng} / \mathrm{ml})$ prior to precocious metamorphosis at the end of the 4th instar, but just before pupation, an increase in JH I levels $(1.68 \pm 1.50 \mathrm{ng} / \mathrm{ml})$ was observed. Although, in this case, the JH I titer had already decreased in the hemolymph of 3rd-instar larvae, precocious metamorphosis always occurred in the 4th stadium, suggesting that anti-JH activity of compound $\mathbf{3 b}$ was counteracted by $\mathrm{JH}$ activity of $\mathbf{3 b}$ itself, present in high concentration during the 3 rd stadium.

As previously described, precocious metamorphosis is well known to be induced by $\mathrm{JH}$ deficiency in the larval stage; however, we have found that the precocious metamorphosisinducing activity of some 1,5-disubstituted imidazoles is completely reversible by the dietary administration of 20-E, suggesting that a temporary decline of ecdysteroid titers in the larval hemolymph might also cause precocious methamorphosis. ${ }^{17)}$ We therefore determined the 20-E titer in hemolymph by LC-MS/MS. Compound $\mathbf{3 b}$ had no significant effect on the 20-E titer during the 3rd stadium (Fig. 3B). Furthermore, the 20-E titer in 4th instar larvae treated with compound $\mathbf{3 b}$ showed a profile very similar to that in control 5th instar larvae before pupation. These results indicate that compound $\mathbf{3 b}$ induced precocious metamorphosis by decreasing 
$\mathrm{JH}$ levels in hemolymph of 3rd and 4th instar larvae.

In conclusion, we found that ethyl 4-[(6-methoxy-2,2-dimethyl-2H-chromen-7-yl)methoxy]benzoate (3b) was a structurally novel anti-JH agent. Although compound $\mathbf{3 b}$ showed $\mathrm{JH}$ activity as well as anti-JH activity, it clearly decreased the JH I titer in hemolymph. Compound $\mathbf{3 b}$ is therefore a reasonable lead compound for the generation of genuine anti-JH agents showing no $\mathrm{JH}$ activity.

\section{Acknowledgments}

We are grateful to Prof. Hiromichi Yoshikawa for kindly allowing us the use of the Applied Biosystems API2000. We also thank Ms. Miho Nakamura and Mr. Seiji Nishikawa for technical support. This work was supported by a grant-in-aid to E.K. for scientific research (no. 17208007) from the Ministry of Education, Culture, Sports, Science, and Technology of Japan.

\section{References}

1) L. I. Gilbert, N. A. Granger and R. M. Roe: Insect Biochemistry and Molecular Biology 30, 617-644 (2000).

2) G. B. Staal: Ann. Rev. Entomol. 31, 391-429 (1986).

3) M. Castillo, P. Moya, F. Couillaud, M. D. Garcera and R. Martinez-Pardo: Arch. Insect Biochem. Physiol. 37, 287-294 (1998).

4) K. Furuta, K. Ashibe, H. Shirahashi, N. Fujita, H. Yamashita, N. Yamada and E. Kuwano: J. Pestic. Sci. 32, 99-105 (2007).
5) S. R. Palli, L. M. Riddiford and K. Hiruma: Insect Biochem. 21, 7-15 (1991).

6) L. Eyrolles, H. Kagechika, E. Kawachi, H. Fukasawa, T. Iijima, Y. Matsushima, Y. Hashimoto and K. Shudo: J. Med. Chem. 37, 1508-1517 (1994).

7) T. Yoshida, T. Shiotsuki and E. Kuwano: J. Pestic. Sci. 25, 253 258 (2000).

8) N. Fujita, K. Furuta, K. Ashibe, S. Yoshida, N. Yamada, T. Shiotsuki, M. Kiuchi and E. Kuwano: J. Pestic. Sci. 33, 383-386 (2008).

9) A.Ichikawa, Y. Ono, K. Furuta, T. Shiotsuki and T. Shinoda: $J$. Chromatography A 1161, 252-260 (2007)

10) F. N. Munyiri and Y. Ishikawa: J. Insect Physiol. 50, 1075-1081 (2004).

11) R. Futahashi and H. Fujiwara: Science 319, 1061 (2008).

12) J. F. Stevens, R. L. Reed and J. T. Morre: J. Agric. Food Chem. 56, 3945-3952 (2008).

13) W. S. Bowers, T. Ohta, J. S. Cleere and P. A. Marsella: Science 193, 542-547 (1976)

14) D. Charles Z., Synth. Comm. 26, 4267-4273 (1996).

15) G. Casiraghi, G. Casnati, M. Cornia, A. Pochini, G. Puglia, G. Sartori, P. Ungaro, J. Chem. Soc., Perkin Trans. 1 318-321 (1978).

16) S. Niimi and S. Sakurai: J. Insect Physiol. 43, 875-884 (1997).

17) E. Kuwano, T. Hisano, M. Sonoda and M. Eto: Biosci. Biotechnol. Biochem. 58, 1309-1310 (1994). 